\title{
Rho GTPase-Activating Protein 32
}

National Cancer Institute

\section{Source}

National Cancer Institute. Rho GTPase-Activating Protein 32. NCI Thesaurus. Code C131141.

Rho GT Pase-activating protein 32 (2087 aa, $231 \mathrm{kDa}$ ) is encoded by the human ARHGAP32 gene. This protein is involved in the regulation of signaling mediated by both Rho family GT Pases and the NMDA receptor. 